\title{
Pengaruh Lama Inkubasi Soyghurt Menggunakan Inokulan dengan Penambahan Bifidobacterium sp. Terhadap Daya Hambat Bacillus cereus
}

\author{
Ika Fitriani ${ }^{1}$, Dyah Fitri Kusharyati ${ }^{1}$, dan P. Maria Hendrati ${ }^{1)}$ \\ ${ }^{1)}$ Fakultas Biologi Universitas Jenderal Soedirman \\ JI. Dr. Soeparman 63, Purwokerto, 53122 \\ *email : dfitri.k@gmail.com
}

\begin{abstract}
Lactic acid bacteria (LAB) are used in the making of soyghurt such Lactobacillus bulgaricus, Streptococcus thermophillus, and Bifidobacterium sp. with optimum growth temperature at $36^{\circ}-37^{\circ} \mathrm{C}$ and the incubation time ranges from 1-2 days. LAB is known able to produce bacteriocins that can inhibit pathogenic bacteria in the digestive tract such as Bacillus cereus. The purpose of this study was to determine the ratio of LAB on soyghurt on inhibition of $B$. cereus, determine the length of incubation soyghurt with the addition of Bifidobacterium sp. on the growth of $B$. cereus, and determine the effect of $\mathrm{LAB}$ concentrations and longer incubation at soyghurt on the growth of $B$. cereus. The results show a comparison of LAB ( $L$. bulgaricus : $S$. thermophillus : Bifidobacterium $\mathrm{sp}$.) 1: 1: 1 (K1) on soyghurt able to inhibit $B$. cereus. Long incubation soyghurt with the addition of Bifidobacterium sp. optimal at 24 hour on the growth of $B$. cereus. LAB concentration with a long incubation at soyghurt not able to increase the growth inhibitory B.cereus.
\end{abstract}

Keywords : Bifidobacterium sp., comparison, incubation time, soyghurt, fermentation temperature.

\section{Pendahuluan}

Soyghurt adalah susu kedelai yang difermentasi oleh bakteri probiotik, karena susu kedelai diketahui memiliki sumber prebiotik alami (Winarno, 1993). Pembuatan soyghurt yang baik ditentukan melalui masa fermentasi susu kedelai oleh bakteri asam laktat (BAL). Faktorfaktor yang mempengaruhi fermentasi diantaranya suhu, dan lama inkubasi (Winarno, 1980). Lama inkubasi dalam fermentasi soyghurt berperan penting dalam berhasil atau tidaknya suatu soyghurt terbentuk karena BAL yang terdapat dalam yoghurt memerlukan waktu yang berbeda-beda untuk tumbuh.

Hal baru yang digunakan untuk memperoleh manfaat kesehatan dari organisme probiotik adalah dengan menambahkan strain bakteri lain seperti Bifidobacterium, selain dua kultur starter yang biasa digunakan yaitu Streptococcus thermophillus dan Lactobacillus bulgaricus. Bifidobacterium memiliki bentuk batang, bersifat anaerob,
Gram positif, tidak berspora, heterofermentatif, dansuhu optimal pertumbuhan $36-37^{\circ} \mathrm{C}$. Bifidobacterium tidak tumbuh pada $\mathrm{pH}$ diatas 8,0 atau dibawah 4,5. Bifidobacterium memproduksi asam asetat dan asam laktat (Nakazawa \& Hosono, 1988). Bakteri Asam Laktat memiliki syarat sebagai probiotik menurut Food and Agriculture Organization (2001), menunjukkan bahwa salah satunya adalah harus mempunyai aktivitas antimikroba dengan memproduksi substansi penghambat seperti asam laktat dan senyawa peptida antimikroba yang bernama bakteriosin. Bakteri patogen yang merugikan dalam pencemaran makanan dan saluran pencernaan salah satunya ialah Bacillus cereus.

Pertumbuhan $B$. cereus perlu dihambat bila jumlahnya melebihi $10^{6}$ cfu/gram makanan, jumlah ini dinyatakan sebagai dosis infektif dan dapat berisiko terhadap kesehatan (Badan Standarisasi 
Nasional, 2009). Penelitian mengenai pengaruh soyghurt menggunakan inokulan yang ditambah dengan

\section{Metode Penelitian}

\section{Rancangan percobaan}

Metode yang digunakan dalam penelitian ini adalah metode eksperimental menggunakan Rancangan Acak Lengkap (RAL) pola faktorial. Faktor pertama yaitu lama inkubasi soyghurt yang diberi penambahan Bifidobacterium sp. pada suhu $37^{\circ} \mathrm{C}$ dan faktor kedua adalah perbandingan konsentrasi Bifidobacterium sp. pada soyghurt. Setiap perlakuan diulang sebanyak 3 kali.

Cara kerja

1. Pembuatan suspensi biakanS. thermophillus, L. bulgaricus dan Bifidobacterium sp. (Oxoid, 1980)

Hasil peremajaaqn $S$. thermophillus, $L$. bulgaricus, dan Bifidobacterium sp. masing-masing diinokulasikan pada media MRS Broth sebanyak 1 ose secara terpisah dan diinkubasi pada suhu $37^{\circ} \mathrm{C}$ selama 1-2 hari hingga terbentuk kekeruhan pada media. Kultur murni pada media deMann Rogosa Sharpe Broth (MRSB) inilah yang akan digunakan dalam tahapan pembuatan starter soyghurt.

2. Pembuatan starter $S$. thermophillus (Koroleva, 1991)

Proses pembuatan starter $S$. thermophillus sebanyak $8,5 \mathrm{~g}$ susu bubuk skim, $10 \mathrm{~g}$ sukrosa, $0,1 \mathrm{~g}$ ekstrak ragi, dan akuades $100 \mathrm{~mL}$ disterilisasi dengan autoklaf kemudian ditambah dengan $1 \%$ $S$. thermophillus yang telah diukur OD \pm $0,5(\lambda=600 \mathrm{~nm})$ dan dinamakan media tumbuh baru (Media A). Setelah itu diinkubasi selama 12 jam dengan suhu $37^{\circ} \mathrm{C}$ dan kultur tersebut disebut kultur induk. Proses selanjutnya membuat feed starter yaitu dengan cara menambahkan $3 \mathrm{~mL}$ kultur induk kedalam media tumbuh baru (Media B) sebanyak $97 \mathrm{~mL}$ kemudian diinkubasi selama 6 jam dengan suhu $37^{\circ} \mathrm{C}$ sampai terkoagulasi. Kultur ini selanjutnya akan dijadikan bulk starter yaitu dengan cara menambahkan $3 \mathrm{~mL}$ feed starter ke dalam media tumbuh baru (Media C) sebanyak $97 \mathrm{~mL}$
Bifidobacterium sp. terhadap pertumbuhan $B$. cereus saat ini belum dilakukan.

selanjutnya diinkubasi selama 8 jam pada suhu $37^{\circ} \mathrm{C}$.

3. Pembuatan starter L. bulgaricus dan Bifidobacterium sp. (Koroleva, 1991)

Proses pembuatan starter yaitu $8,5 \mathrm{~g}$ susu bubuk skim dan $100 \mathrm{~mL}$ akuades dicampur lalu sterilisasi menggunakan autoklaf, kemudian ditambah dengan $1 \%$ L. bulgaricus dan Bifidobacterium sp. yang telah diukur OD $\pm 0,5(\lambda=600 \mathrm{~nm})$ dan dinamakan media tumbuh baru (Media A). Kemudian diinkubasi selama 24 jam dengan suhu $37^{\circ} \mathrm{C}$ dan kultur tersebut disebut kultur induk. Proses selanjutnya membuat feed starter yaitu dengan cara menambahkan $3 \mathrm{~mL}$ kultur induk ke dalam media tumbuh baru (Media B) sebanyak $97 \mathrm{~mL}$ kemudian diinkubasi selama 29 jam dengan suhu $37^{\circ} \mathrm{C}$ sampai terkoagulasi. Kultur ini yang selanjutnya akan dijadikan bulk starter yaitu dengan cara menambahkan $3 \mathrm{~mL}$ feed starter ke dalam media tumbuh baru (Media C) sebanyak $97 \mathrm{~mL}$ lalu diinkubasi selama 9 jam yang bersuhu $37^{\circ} \mathrm{C}$.

4. Soyghurt standar (modifikasi Bagiastra, 1984)

Susu kedelai yang telah disiapkan dalam botol bening, ditambahkan dengan susu skim 5\% dan sukrosa sebanyak 5\% dilarutkan hingga volume akhir $1000 \mathrm{~mL}$, diaduk sampai larut. Kemudian dipasteurisasi pada suhu $80-90^{\circ} \mathrm{C}$ selama 30 menit dan dilakukan pendinginan sampai suhu $45^{\circ} \mathrm{C}$. Selanjutnya diinokulasi dengan starter yoghurt sebanyak $3 \mathrm{~mL}$ dengan perbandingan $S$. thermophillus dan L. bulgaricus sebanyak 1:1. Kemudian di kocok beberapa kali, lalu inkubasi pada suhu $37^{\circ} \mathrm{C}$ selama 24 $\operatorname{Jam}\left(\mathrm{K}_{0}\right)$.

5. Soyghurt dengan penambahan Bifidobacterium sp. pada berbagai konsentrasi

Perlakuan $\mathrm{K}_{1}$ dan $\mathrm{K}_{2}$ dilakukan pekerjaan yang sama seperti pembuatan soyghurt standar hanya :

a. Penambahan $3 \mathrm{~mL}$ total starter, dengan perbandingan S. Thermophillu : L. bulgaricus : Bifidobacterium sp. 
sebanyak $1: 1: 1$ diinokulasikan kedalam susu kedelai $\left(\mathrm{K}_{1}\right)$.

b. Penambahan $3 \mathrm{~mL}$ total starter, dengan perbandingan $S$.

Thermophillus : L. bulgaricus :

Bifidobacterium sp. sebanyak $1: 1: 2$ diinokulasikan kedalam susu kedelai $\left(\mathrm{K}_{2}\right)$.

Kemudian ketiga produk soyghurt dengan berbagai konsentrasi tersebut dikocok beberapakali, lalu diinkubasi dengan suhu $37^{\circ} \mathrm{C}$ selama $1 \times 24$ jam.

6. Pengujian aktivitas antimikroba produk soyghurt yang ditambah kultur Bifidobacterium sp. pada $B$. cereus Sebelum uji hambat, kultur $B$. cereus diregenerasi dalam $100 \mathrm{~mL}$ Nutrient Broth (NB) steril pada Erlenmeyer $200 \mathrm{~mL}$. Selanjutnya diinkubasi dalam inkubator bergoyang (shaker incubator) dengan kecepatan $150 \mathrm{rpm}$ selama 24 jam.

7. Daya

hambat

soyghurtBifidobacterium sp. terhadap

$B$. cereus (Uji difusi) (modifikasi Yang

et al., 1992 dan Biswas et al., 1991)

Masing-masing soyghurt standar dan soyghurt yang diberi penambahan Bifidobacterium sp. diambil 4,5 mL. Soyghurt disentrifuge dengan kecepatan $13.000 \mathrm{rpm}$ selama 15 menit. Masingmasing supernatan diukur $\mathrm{pH}$, sampai pH-nya 6,5. Kemudian dipanaskan pada suhu $100^{\circ} \mathrm{C}$ selama 15 menit.Sebanyak $0,1 \mathrm{~mL}$ suspensi $B$. cereus diinokulasikan pada medium Nutrient Agar (NA) (spread plate) kemudian diratakan. Selanjutnya $0,2 \mu \mathrm{l}$ dari supernatan $B$. cereus diteteskan di atas kertas cakram steril dengan diameter $6 \mathrm{~mm}$, diinkubasi

\section{Hasil dan Pembahasan}

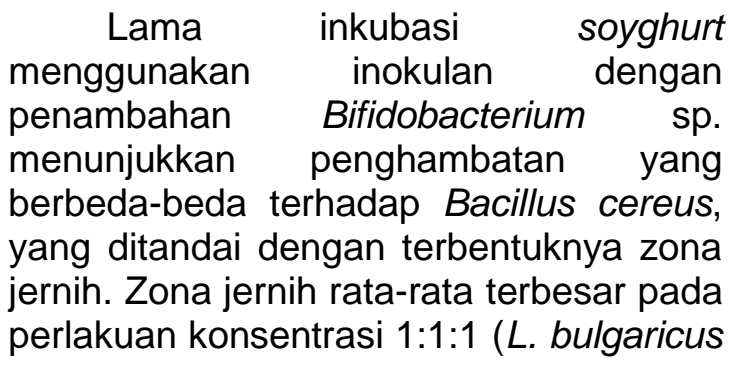

selama 24 jam pada suhu $37^{\circ} \mathrm{C}$, ada tidaknya penghambatan ditandai dengan terbentuknya daerah bening pada bekas tetes (spot) supernatan.Pengamatan uji aktivitas antimikroba dilakukan denga mengukur diameter daerah hambat (DDH) pertumbuhan bakteri yang terbentuk di sekitar kertas cakram dengan penggaris.

8. Pengukuran kadar asam laktat soyghurt (AOAC, 1995)

Soyghurt standar dan soyghurt yang diberi penambahan Bifidobacterium sp. telah siap, maka masing-masing kadar asam laktat yang terkandung dihitung setiap 4 jam sekali selama $1 \times 24$ jam. Sampel diambil sebanyak $10 \mathrm{~mL}$ dan dimasukkan kedalam labu Erlenmeyer laluditambahkan $90 \mathrm{~mL}$ akuades untuk dititrasi dengan $\mathrm{NaOH} 0,1 \mathrm{~N}$. Indikator yang digunakan adalah phenolphtalein $1 \%$ sebanyak 3 tetes dengan perubahan warna dari tak berwarna menjadi merah muda. Menurut syarat mutu yoghurt pada SNI 01-2981-1992, jumlah asam laktat adalah $0,5-2 \%$.

9. Uji Organoleptik (Soekarto, 1985)

Pengujian organolpetik soyghurts. thermophillus : L. bulgaricus : Bifidobactreium sp. (1:1:0, 1:1:1, 1:1:2) dilakukan dengan uji mutu hedonik kepada 10 panelis. Masing-masing soyghurt dimasukan kedalam wadah dan diberi label, lalu diambil satu sendok. Soyghurt yang diberi perlakuan diuji mutu hedonik terhadap tingkat keasaman, kesukaan, aroma, dan warna, kemudian para panelis diberi lembar penilaian

: S. thermophillus : Bifidobacterium sp.) dan lama inkubasi 24 jam (K1T6) yaitu sebesar $9,17 \mathrm{~mm}$, sedangkan rata-rata zona jernih terkecil pada perlakuan konsentrasi 1:1:0 (L. bulgaricus : $S$. thermophillus : Bifidobacterium sp.) pada lama inkubasi 0 jam (KOTO) yaitu sebesar $6,5 \mathrm{~mm}$. 


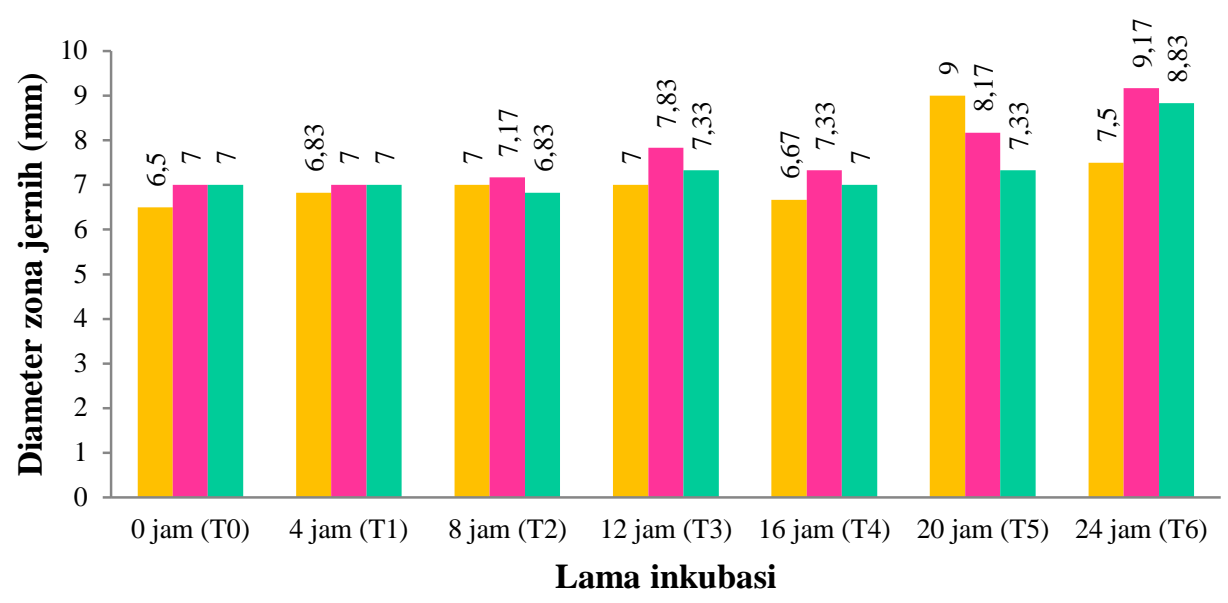

$\varpi \mathrm{K} 0 \backsim \mathrm{K} 1 \backsim \mathrm{K} 2$

Gambar 1. Histogram rata-rata diameter zona jernih yang terbentuk pada berbagai lama inkubasi dan konsentrasi.

Berdasarkan Gambar 1. dapat dilihat bahwa rata-rata zona jernih terbesar pada lama inkubasi 24 jam dilihat dari perbandingan konsentrasi $L$. bulgaricus : $S$. thermophillus : Bifidobacterium sp. berturut-turut 1:1:0 (K0); 1:1:1 (K1); dan 1:1:2 (K2) sebesar $7,5 \mathrm{~mm}, 9,17 \mathrm{~mm}$. dan $8,83 \mathrm{~mm}$. Dari data tersebut dapat dilihat bahwa dengan adanya penambahan Bifidobacterium sp. mampu menghasilkan daya hambat lebih besar terhadap $B$. cereus pada lama inkubasi 24 jam. Hal ini sesuai dengan Gunawan et al. (2014) dalam penelitiannya menyatakanlama inkubasi dan jumlah konsentrasi starter mempengaruhi aktivitas antibakteri soyghurt terhadap pertumbuhan Escherichia coli selama penyimpanan 30 hari. Lama inkubasi 20 jam (T5) pada perbandingan $L$. bulgaricus : $S$. thermophillus (1:1) menunjukkan diameter zona jernih terbesar yaitu $9 \mathrm{~mm}$. Menurut Suryono et al. (2005)bahwa kultur L.bulgaricus dan $S$. thermophillus dapat membentuk koagulan dengan baik setelah inkubasi 20 jam suhu $37^{\circ} \mathrm{C}$ dan $L$. bulgaricus akan tumbuh lebih dahulu untuk mempersiapkan lingkungan yang baik untuk perkembangan $S$. thermophillus.
Menurut Kusumaningrum (2011) fase lag pertumbuhan bakteri probiotik masih sangat rendah, dikarenakan pada fase ini bakteri probiotik masih menyesuaikan dengan lingkungannya yang baru yaitu substrat tempat tumbuhnya. Kecepatan fase lag dipengaruhi oleh substrat karena substrat mempengaruhi kemampuan bakteri probiotik dalam fermentasi sustrat untuk pertumbuhannya. Semakin kompleks senyawa maka lebih membutuhkan waktu yang lama untuk dihidrolisis. Hal tersebut tidak sesuai dengan hasil penelitian, dimana pada lama inkubasi 0 jam sudah terbentuk zona jernih yang menandakan adanya aktifitas dari bakteri probiotik. Zona jernih yang terbentuk memiliki ukuran $6,5-7 \mathrm{~mm}$ dengan diameter kertas cakram sebesar $6 \mathrm{~mm}$. Kemungkinan hasil tidak valid karena adanya kesalahan dalam pengamatan.

Hasil tersebut dinyatakan juga dengan hasil analisis ragam (Uji $\mathrm{F})$ dengan tingkat ketelitian 99\% dan 95\% untuk mengetahui pengaruh perlakuan terhadap diameter zona jernih yang terbentuk. Hasil Uji F dapat dilihat pada Tabel 1. 
Tabel 1. Analisis ragam lama inkubasi dan konsentrasi terhadap diameter zona hambat yang terbentuk.

\begin{tabular}{ccccccc}
\hline \multirow{2}{*}{ SV } & \multirow{2}{*}{ DB } & \multirow{2}{*}{ JK } & \multirow{2}{*}{ KT } & F Hit & \multicolumn{2}{c}{ F. Tab } \\
\cline { 5 - 7 } & & & & & 0.05 & 0.01 \\
\hline $\mathrm{P}$ & 20 & 350.952 & 17.548 & $2.1158^{*}$ & 1.83 & 2.34 \\
\hline $\mathrm{K}$ & 2 & 23.095 & 11.548 & 13.923 & 3.22 & 5.15 \\
\hline $\mathrm{T}$ & 6 & 238.175 & 39.696 & $4.7863^{* *}$ & 2.32 & 3.27 \\
\hline $\mathrm{KXT}$ & 12 & 89.683 & 0.7474 & 0.9011 & 1.99 & 2.64 \\
\hline $\mathrm{G}$ & 42 & 348.333 & 0.8294 & & $\mathrm{SD}=$ & 0.911 \\
\hline Total & 62 & 699.286 & & & $\mathrm{KK}=$ & $12299 \%$ \\
\hline
\end{tabular}

Keterangan:

* : : Berbeda nyata

** : : Berbeda sangat nyata

K : Perlakuan Konsentrasi

$\mathrm{T} \quad$ : Perlakuan Lama inkubasi

Berdasarkan Tabel 1. secara statistik dapat diketahui bahwa perlakuan lama inkubasi berbeda sangat nyata, sedangkan untuk konsentrasi penambahan Bifidobacterium sp. dan interaksi antar konsentrasi dengan lama inkubasi berbeda tidak nyata. Hal tersebut mengindikasikan bahwa lama inkubasi sangat berpengaruh terhadap diameter zona hambat yang terbentuk, sedangkankonsentrasidaninteraksi antara konsentrasi dan lama inkubasi tidak berpengaruh terhadap diameter zona hambat.

Hasil di atas berbeda dengan hasil pengamatan yang menunjukkan bahwa perbandingan BAL (L. bulgaricus : $S$. thermophillus : Bifidobacterium sp. 1:1:1) mampu menghambat $B$. cereus. Perlakuan konsentrasi optimum yang menghasilkan diameter rata-rata zona jernih terbesar terhadap B.cereus yaitu $L$. bulgaricus : $S$. thermophillus : Bifidobacterium sp. 1:1:1 (K1). Hasil tersebut sesuai hipotesis pertama penambahan BAL dengan perbandingan $L$. bulgaricus $: S$. thermophillus : Bifidobacterium $\mathrm{sp}$. sebesar (1:1:1) pada soyghurt mampu meningkatkan daya hambat pertumbuhan $B$. cereus. Fardiaz (1992) juga menyatakan, bahwa kemampuan suatu zat antimikroba dalam menghambat pertumbuhan mikroba dipengaruhi oleh beberapa faktor, misalnya waktu penyimpanan, suhu lingkungan, sifat-sifat mikroba (jenis, umur, dan keadaaan mikroba), sifat-sifat fisik dan kimia makanan, termasuk kadar air, $\mathrm{pH}$, serta jenis dan jumlah senyawa di dalamnya.

Lama inkubasi 24 jam (T6) adalah yang terbaik untuk ketiga jenis isolat dalam menghambat pertumbuhan $B$. cereus yaitu sebesar $9,17 \mathrm{~mm}$. Hal ini sebanding dengan penelitian Gunawan et al. (2014) bahwa lama penyimpanan soyghurt dengan starter Bifidobacterium BBIV, L. bulgaricus, dan S. thermophillus dalam menghambat pertumbuhan Escherichia coli yang terbaik yaitu 30 hari dengan rata-rata diameter zona jernih yang terbentuk sebesar 11,4 $\mathrm{mm}$. Terbentuknya asam laktat oleh BAL dapat menyebabkan penurunan $\mathrm{pH}$ sehingga pertumbuhan bakteri Gram positif dan Gram negatif yang tidak tahan $\mathrm{pH}$ rendah akan terhambat (Fardiaz, 1992).

Hasil uji beda nyata jujur menunjukkan perlakuan lama inkubasi berpengaruh terhadap daya hambat $B$. cereus. Rata-rata diameter zona jernih yang terbentuk berturut-turut dari yang terbesar hingga terkecil berdasarkan lama inkubasi yaitu T6, T5, T3, T2, T4, T1, T0 ditunjukkan pada tabel 2 . 
Tabel 2. Hasil Uji Beda Nyata (BNJ) perlakuan lama inkubasi soyghurt selama 24 jam.

\begin{tabular}{ll}
\hline Perlakuan & Diameter zona jernih $(\mathrm{mm})$ \\
\hline T6 & $8,50 \pm 1,41 \mathrm{a}$ \\
T5 & $8,17 \pm 1,39 \mathrm{ab}$ \\
T3 & $7,39 \pm 0,89 \mathrm{abc}$ \\
T2 & $7,00 \pm 0,50 \mathrm{bc}$ \\
T4 & $7,00 \pm 0,43 \mathrm{bc}$ \\
T1 & $6,94 \pm 0,53 \mathrm{bc}$ \\
T0 & $6,83 \pm 0,56 \mathrm{c}$ \\
\hline
\end{tabular}

Keterangan : Angka yang diikuti huruf yang sama berbeda tidak nyata pada BNJ 5\%

Soyghurt dengan perlakuan lama inkubasi selama 0 jam (T0) menghasilkan diameter zona hambat terkecil dibandingkan dengan yang lainnya yaitu $6,83 \mathrm{~mm}$. Hal ini dikarenakan starter yang diinokulasikan kedalam susu kedelaimasih beradaptasi dengan media tumbuhnya. Judoamidjojo et al. (1992), menyatakan bahwa mikroorganisme perlu mengetahui makromolekul media saat dipindah-pindah dari lingkungan satu ke lingkungan lain, dalam waktu ini massa sel dapat berubah tanpa mengubah jumlah sel. Kerja starter ( $L$. bulgaricus, $S$. thermophillus, dan Bifidobacterium sp.) yang masih beradaptasi menjadi tidak maksimal untuk menghambat pertumbuhan $B$. cereus.

Soyghurt dengan perlakuan lama inkubasi 24 jam (T6) menghasilkan diameter zona hambat terbesar yaitu 8,50 $\mathrm{mm}$. Hasil ini sesuai dengan hipotesis ke dua yang menyatakan bahwa pertumbuhan Bifidobacterium sp. pada soyghurt akan optimal dengan lama inkubasi 24 jam dalam menghambat $B$ cereus. Menurut Daud et al. (2009) jumlah koloni bakteri $B$. bifidum dalam media yang mengandung oligosakarida paling tinggi dicapai pada 24 jam masa inkubasi. Menurut Khoiriyah et al (2014) lama inkubasi 24 jam Lactobacillus sp. $\mathrm{RED}_{4}$ merupakan waktu optimum menghasilkan antimikroba dalam menghambat $B$. cereus, hal ini disebabkan resistensi bakteri tersebut.

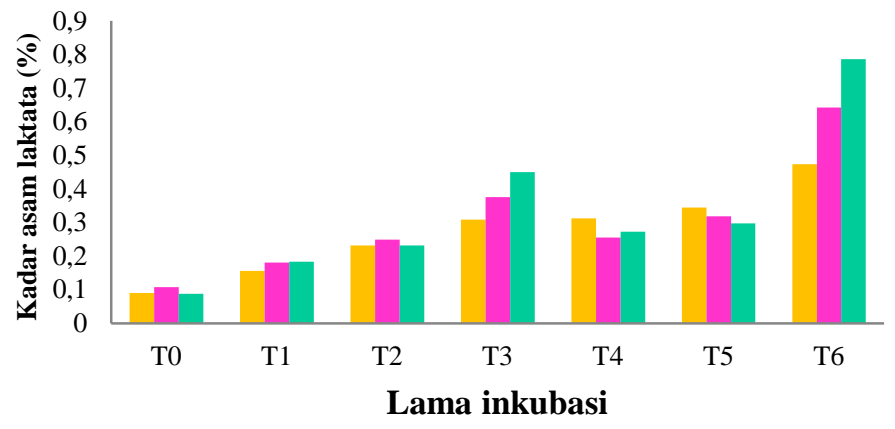

$\because \mathrm{K} 0 \square \mathrm{K} 1 \square \mathrm{K} 2$

Gambar 2. Histogram kadar asam laktat pada berbagai lama inkubasi dan konsentrasi.

Hasil uji kadar asam laktat soyghurt dengan penambahan Bifidobacterium sp. dan lama inkubasi 0 jam sebesar 0,087 $0,108 \%$. Lama inkubasi 0 jam BAL masih mengalami fase lag (fase adaptasi) dimana seharusnya belum menghasilkan asam laktat. Kadar asam laktat tertinggi yaitu pada konsentrasi $L$. bulgaricus : $S$. thermophillus : Bifidobacterium sp. 1:1:2 (K2) dan lama inkubasi 24 jam (T6) sebesar 0,786\%. Keasaman yoghurt produksi Indonesia menurut Standar
Industri Indonesia (SII-07 17-1990) berkisar 0,5 sampai $2 \%$ asam laktat (Suryono et al., 2005).

Gunawan et al. (2014) menyatakan bahwa kadar asam laktat soyghurt yang dihasilkan selama 30 hari penyimpanan meningkat menjadi $0,4-1,4 \%$, besarnya kandungan asam laktat yang dihasilkan diduga juga menghambat pertumbuhan bakteri yang ada di dalam soyghurt. Semakin lama waktu inkubasi $\mathrm{pH}$ semakin kecil, penurunan $\mathrm{pH}$ yang terjadi 
diakibatkan oleh peningkatan kadar asam organik yang diduga sebagai asam laktat dan asam asetat (Khoiriyah et al., 2014). Menurut Syahniar (2009) penurunan pH BAL disebabkan oleh adanya asam-asam organik yang terbentuk selama pertumbuhan dan merupakan senyawa metabolit primer yang dihasilkan oleh bakteri tersebut. Menurut Mourad et al. (2005) BAL mampu menghasilkan metabolit primer yang memiliki sifat antimikroba. Senyawa tersebut dapat berupa asam laktat, hidrogen peroksida, dan bakteriosin.

Asam laktat yang dihasilkan oleh BAL juga mempengaruhi hasil organoleptik dari soyghurt. Hasil uji organoleptik dilakukan dengan uji kesukaan (hedonik) terhadap 10 panelis berdasarkan citarasa yang meliputi rasa, kesukaan, aroma, dan warna. Panelis mencoba soyghurt dengan konsentrasi penambahan Bifidobacterium $\mathrm{sp}$. K0 (1:1:0), K1 (1:1:1), dan K2 (1:1:2) setiap perlakuan lama inkubasi yaitu 0 jam (T0), 4 jam (T1), 8 jam (T2), 12 jam (T3), 16 jam (T4), 20 jam (T5), 24 jam (T6). Hasil ujihedonik tingkat keasaman rata-rata

\section{Simpulan dan Saran}

\section{Simpulan}

Berdasarkan uraian hasil dan pembahasan, maka diperoleh kesimpulan sebagai berikut :

1. Perbandingan BAL pada soyghurt dengan perbandinganL. bulgaricus:S. thermophillus : Bifidobacterium $\mathrm{sp}$. $1: 1: 1$ (K1) mampu menghambat $B$. cereus.

2. Lama inkubasi soyghurt dengan penambahan Bifidobacterium sp.

\section{Daftar Pustaka}

AOAC. 1995. Official Methods of Analysis of the Association of Official Agricultural Chemist. Washington : AOAC Int.

Bagiastra, I. G. 1984. Mempelajari Mutu Dan Stabilitas Minuman Botol Yoghurt Kedelai. Skripsi. Fakultas tertinggi yaitu T6K2 sebesar 2,50 yaitu rasa asam. Hasil uji hedonik kesukaan pada TOKO sebesar 2,87 rasa disukai oleh panelis. Hasil uji hedonik aroma yaitu T6K2 sebesar 1,57 yaitu aroma agak tajam. Hasil uji hedonik warna T5K2 pada 2,40 yaitu soyghurt berwarna putih kekuningan. Soyghurt dengan konsentrasi L. bulgaricus : $S$. thermophillus : Bifidobacterium sp. 1:1:0 (K0) dan lama inkubasi jam ke-0 (T0) yang memiliki tekstur juga disukai paling banyak dari panelis karena pada saat itu bentuk susu kedelai belum memisah dan rasanya masih manis. Hal ini sesuai dengan pernyataan Suryono et al. (2005) penggunaan Bifidobacteria dalam campuran bersama bakteri kultur yoghurt berpengaruh meningkatkan keasaman dan kekentalan. Thiel T. (1999) menyatakan aroma dan rasa soyghurt dipengaruhi oleh asam laktat yang diproduksi oleh $L$. bulgaricus dan $S$. thermophillus. L. bulgaricus memberikan aroma yang khas pada soyghurt sedangkan $S$. thermopillus menghasilkan rasa asam .

optimal pada 24 jam terhadap pertumbuhan $B$. cereus.

3. Konsentrasi BAL dengan lama inkubasi pada soyghurt tidak mampu meningkatkan daya hambat pertumbuhan B.cereus.

\section{Saran}

Berdasarkan hasil penelitian, saran yang dapat diajukan yaitu : penggunaan metode uji selain menggunakan kertas cakram (uji difusi) dapat dilakukan dengan spektrofotometer (Uji turbidimetri) untuk mengkonfirmasi hasil secara kuantitatif.

Teknologi Pertanian. Institut Pertanian Bogor, Bogor.

Badan Standar Nasional. 2009. Batas Maksimum Cemaran Mikroba dalam Pangan: Standar Nasional Indonesia (SNI) 7388.

Biswas, S. R., Purbita Ray, M. C. Johnson and B. Ray. 1991. Influence of Growth Conditions on 
the Production of a Bacteriocin, Pediocin AcH, by Pediococcus acidilactici $\mathrm{H}$. Applied Environmental Microbiology 57(4):1265.

Daud, M. Wiranda, G. P., Komang, G. W. dan Agus, S. 2009. Pengujian Secara In Vitro Oligosakarida dari Ekstrak Tepung Buah Rumbia (Metroxylon sago Rottb.) sebagai Sumber Prebiotik. Agripet. Institut Pertanian Bogor. Vol.9 No.2.

[FAO]. Food and Agriculture Organization. 2001. Health and Nutritional Properties Of Probiotic In Food Including Powder Milk With Live Lactic Bacteria.

Fardiaz, S. 1992. Mikrobiologi Pangan I. Jakarta: PT Gramedia.

Gunawan, B. A., D. Fitri, dan M. Hendrati. 2014. Pengaruh Penambahan Bifidobacterium BBIV dan Lama Inkubasi pada Soyghurt Terhadap Pertumbuhan Escherichia coli. Skripsi. Universitas Jendral Soedirman, Purwokerto.

Judoamidjojo, M., Abdul, A. D., Endang, G. S. 1992. Teknologi Fermentasi. Rajawali Pers.

Khoiriyah, H., Puji, A., Afghani, J. 2014. Penentuan Waktu Inkubasi Optimum Terhadap Aktivitas Bakteriosin Lactobacillus sp. RED 4 . JKK. Vol (3)1. HIm 7-12. ISSN 2303-1077.

Koroleva, N. S. 1991. Product Prepared with Lactic Acid Bacteria and Yeast. Didalam : Robinson RK, editor. Therapeutic Properties of Fermented Milks. London: Elsevier Applied Science.

Kusumaningrum, A.P. 2011. Kajian Total Bakteri Probiotik dan Aktivitas Antioksidan Yoghurt Tempe dengan Variasi Substrat. Skripsi. Fakultas Pertanian. Universitas Sebelas Maret, Surakarta.
Mourad, K., Halima, Z. K., and NourEddine, K. 2005. Detection and Actifity of Plantaricin OL 15 a Bacteriocin Produced by Lactobacillus plantarum OL 15 Isolated from Algerian Fermented Olive, Grasasy Aceites 56 (3): 192197.

Nakazawa, Y. dan A. Hasono. 1988. Function of Fermented Milk : Challenges for The Health Science. Elsevier Applied Science Publisher, London.

Oxoid. 1980. The Oxoid Mannual of Culture Media, Ingredients, and Other Laboratory Services. Edisi ke5. Basingtoke : Oxoid.

Soekarto ST. $1985 . \quad$ Penilaian Organoleptik Untuk Industri Pangan dan Hasil Pertanian. Bharatara Karya Aksara. Jakarta.

Suryono, Sudono, A., Sudarwanto,M., dan Apriyantono, A. 2005. Studi Pengaruh Penggunaan Bifidobacteria terhadap Flavor Yoghurt. Jurnal teknologi dan Industri Pangan. Vol.XVI No.1

Syahniar, T. 2009. Produksi dan Karakterisasi Bakteriosin asal Lactobacillus plantarum 1 A5 serta Aktivitas Antimikrobanya Terhadap Bakteri Patogen. Departemen IImu Produksi dan teknologi Peternakan, Fakultas Peternakan IPB. Skripsi. Bogor

Winarno, F.G. Srikandi,F. Dedi, F. 1980. Pengantar Teknologi Pangan. Jakarta: Gramedia Pustaka. Hal : 63:65.

Winarno. 1993. Pangan (Gizi, Teknologi dan Konsumen). Jakarta: Gramedia Pustaka.

Yang, R., M.C. Jhonson and B Ray. 1992. Novel Mwthod to Extract Large Amounts of Bacteriocin from Lactic Acid Bacteria. Applied Environmental Microbiology 58(10): 3355-3359 